\title{
Founder mutations among the Dutch
}

\author{
Maurice PA Zeegers ${ }^{1,2}$, Frans van Poppel $^{3}$, Robert Vlietinck ${ }^{4}$, Liesbeth Spruijt ${ }^{4}$ \\ and Harry Ostrer*,5
}

\begin{abstract}
${ }^{1}$ Department of Epidemiology, Maastricht University, PO Box 616, 6200 MD, Maastricht, The Netherlands; ${ }^{2}$ Academic Centre of General Practice, Catholic University Leuven, Kapucijnenvoer 33- Blok J 3000 Leuven, Belgium; ${ }^{3}$ Netherlands Interdisciplinary Demographic Institute (NIDI), PO Box 11650, 2502 AR, Denhaag, The Netherlands; ${ }^{4}$ Department of Genetics and Cell Biology, Maastricht University, PO Box 616, 6200 MD, Maastricht, The Netherlands; ${ }^{5}$ New York University School of Medicine, 550 First Avenue, MSB 136, New York, NY 10016, USA
\end{abstract}

Many genetic disorders demonstrate mutations that can be traced to a founder, sometimes a person who can be identified. These founder mutations have generated considerable interest, because they facilitate studies of prevalence and penetrance and can be used to quantify the degree of homogeneity within a population. This paper reports on founder mutations among the Dutch and relates their occurrence to the history and demography of the Netherlands. International migration, regional and religious endogamy, and rapid population growth played key roles in shaping the Dutch population. In the first millenniums $B C$ and $A D$, the Netherlands were invaded by Celts, Romans, Huns, and Germans. In more recent times, large numbers of Huguenots and Germans migrated into the Netherlands. Population growth within the Netherlands was slow until the 19th century, when a period of rapid population growth started. Today, the Dutch population numbers 16 million inhabitants. Several different classes of founder mutations have been identified among the Dutch. Some mutations occur among people who represent genetic isolates within this country. These include mutations for benign familial cholestasis, diabetes mellitus, type I, infantile neuronal ceroid lipofuscinosis, L-DOPA responsive dystonia, and triphalangeal thumb. Although not related to a specific isolate, other founder mutations were identified only within the Netherlands, including those predisposing for hereditary breast-ovarian cancer, familial hypercholesterolemia, frontotemporal dementia, hereditary paragangliomas, juvenile neuronal ceroid lipofuscinosis, malignant melanoma, protein C deficiency, and San Filippo disease. Many of these show a regional distribution, suggesting dissemination from a founder. Some mutations that occur among the Dutch are shared with other European populations and others have been transmitted by Dutch émigrés to their descendents in North America and South Africa. The occurrence of short chromosomal regions that have remained identical by descent has resulted in relatively limited genetic heterogeneity for many genetic conditions among the Dutch. These observations demonstrate the opportunity for gene discovery for other diseases and traits in the Netherlands.

European Journal of Human Genetics (2004) 12, 591-600. doi:10.1038/sj.ejhg.5201151

Published online 10 March 2004

Keywords: Netherlands; founder mutation; population genetics; demography

*Correspondence: Dr H Ostrer, New York University School of Medicine, 550 First Avenue, MSB 136, New York 10016, USA. Tel: + 1212 263-7596; Fax: + 1212 263-3477; E-mail: ostreh01@med.nyu.edu Received 3 July 2003; revised 11 October 2003; accepted 13 November 2003

\section{Introduction}

Many Mendelian disorders demonstrate mutations that can be traced to a founder, often one whose name is unknown, but whose existence can be inferred from the unique chromosomal background on which the mutation 
occurred. ${ }^{1}$ Some founder mutations may be a major cause of the disorder, because they lead to a specific phenotype the disease occurs only if that mutation is present. ${ }^{2,3}$ Alternatively, there is no specific correlation with phenotype, but the reproductive history within a given population led to a relatively high frequency for the mutation and, thus, to its becoming a major cause of a disease. ${ }^{4}$

Founder mutations have generated considerable interest among human geneticists. Testing for one or a few prevalent founder mutations is more efficient than testing for many rare mutations., 6 This enhanced efficiency of testing has led to many studies about the prevalence and penetrance of these mutations. ${ }^{7,8}$ Founder mutations demonstrate linkage disequilibrium (LD) with neighboring genetic markers. ${ }^{1}$ Using LD-mapping, genes can be identified without prior knowledge of the founder mutation. ${ }^{9-11}$ When the founder is not identified, the size of the LD intervals can provide a timing mechanism (coalescence time) for when the mutation arose in the given population. ${ }^{10}$ Identification of the same founder mutations in different populations has been useful for determining the relatedness of these populations. ${ }^{12}$

Founder mutations have been identified both in stable populations as well as in populations with a migratory history. ${ }^{12}$ In stable populations, the mutation may have arisen within the population itself or may have been brought into the population by an immigrant. In migratory populations, the mutation was introduced by a founder whose descendants either reproduced with other immigrants or with a local population. Typically, a period of endogamy ensued as the result of geographic, linguistic or religious isolation, often a combination of these factors. In turn, other events, including selection and genetic drift, operated to influence the frequency of the founder mutation.

Founder mutations occur in several European populations, some of which have been reviewed previously. ${ }^{13,14}$ Here, we report on founder mutations among the Dutch and relate their occurrence to the history and demography of the Netherlands, including subsequent migration to North and South America and South Africa. The founder mutations among the Dutch may be explained on the basis of migration, endogamy, and rapid population growth.

\section{Dutch origins}

The Dutch are descended from a group of Homo sapiens who settled Europe during the Paleolithic (40000 years ago) and Neolithic (10000 years ago) periods. ${ }^{15}$ These settlers originated in the Middle Eastern and brought a discrete set of Y chromosomal and mitochondrial haplotypes, Indo-European languages, agriculture, and pottery. ${ }^{16-18}$ The settlers were hunters, who lived in communities of about 50 people at a population density of one person per $15-50 \mathrm{~km}^{2} .{ }^{15}$ This means that each community controlled an area of $750-2500 \mathrm{~km}^{2}$. Over the territory of the present Netherlands $\left(41536 \mathrm{~km}^{2}\right)$, there must have been about 3000 inhabitants (Figure 1).

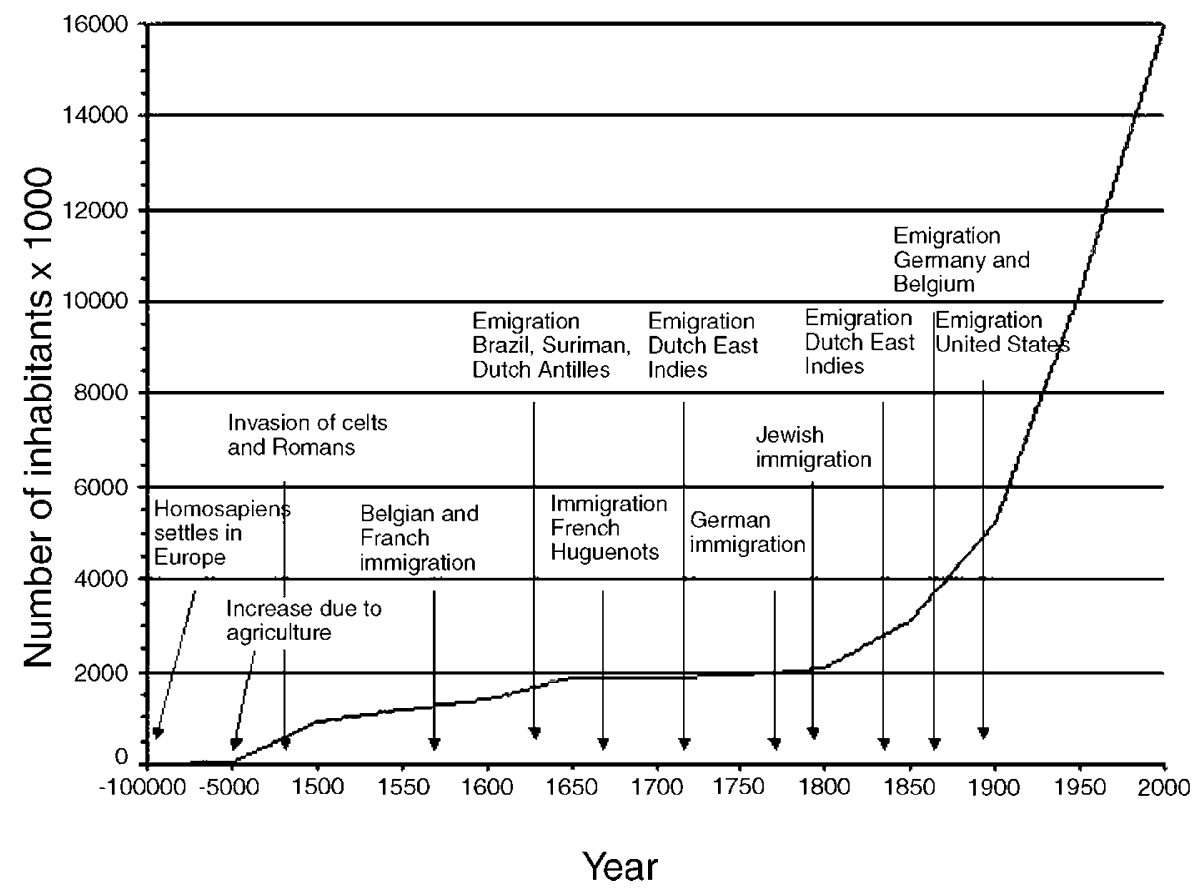

Figure 1 Population growth in the Netherlands: $10000 \mathrm{BC}$ to $2000 \mathrm{AD}$, indicating the major demographic events. 
Agriculture supported higher population densities so that, in the early Bandkeramik period, there were about two inhabitants per square kilometer ${ }^{15}$ Over the territory of the present Netherlands, there must have been about 80000 inhabitants. Several new cultures appeared around this time period of 5000-1000 BC, with the Megalithic monuments as the most prominent examples. ${ }^{19}$ Those tombs were made of large stones shaped as domens or menhirs, and appeared in the farming regions along the Atlantic coast of Europe from the Iberian Peninsula to Denmark, and along the western coasts of England and Ireland. Stonehenge in England is the most famous example.

In the first millennium $\mathrm{BC}$, the Netherlands were invaded by Celts, a people who were successful farmers and excellent copper smiths. ${ }^{20}$ They were descendants of the Iron Age communities that were named for Halstatt in western Austria and La Tène in Switzerland. During the next millennium, other groups settled in the Netherlands. Under Julius Caesar, the Romans invaded the Netherlands around the birth of Christ. A wave of Goths passed through the Netherlands around $400 \mathrm{AD}$, followed by Huns around $450 \mathrm{AD}$, and by the Germans around $800 \mathrm{AD}$ (Figure 1). Regional sovereignty in the Netherlands began around $1000 \mathrm{AD}$.

\section{Demographics of the Netherlands Immigration}

In 1500 , the population of the geographic region of the Netherlands counted between 900000 and 1000000 inhabitants. This number increased to 1.85 million people in 1650, and, then, growth came almost to a standstill. In the 19th century, population growth resumed and, by 1880 , the Dutch population increased to 2.1 million. By 1900, it reached 5.17 million, and by 1950 it doubled again to 10.2 million (Figure 1$).^{21}$

International migration played a key role in shaping the Dutch population. From the late 16th century onward, large numbers of immigrants settled in the Netherlands, attracted by the religious tolerance and economic prosperity of the Dutch Republic. ${ }^{22,23}$ After 1580, 100000 religious and economic refugees fled from Flanders and northern France and settled with their families in the cities of the seaside provinces. A century later, 50000 French Huguenots arrived in the Republic and, again, mostly settled in the cities and towns of the West. From the late 16th century until well into the 19th century, considerable economic migration occurred in the cities of the west, mainly from western Germany and Scandinavia. At the end of the 16th century, several thousand Jewish refugees from the Iberian peninsula arrived in the same area. From the second half of the 18th century onward, some 20000 Jews arrived from Central and Eastern Europe. A rough estimate of the total 17 th and 18 th century migration into the
Netherlands was on the order of half a million people, $60 \%$ of whom came from western Germany. Compared to a national population of two million people in 1800 , these figures suggest that immigration was an important factor for shaping the demography of the Netherlands. Immigration declined after 1800 and did not become a demographic force again until the mid-20th century (Figure 1). ${ }^{22,23}$

\section{Emigration}

Emigration was also a demographic force. Large numbers of indigenous Dutch people left the country during the past several centuries. In the 19th century, many Dutch people emigrated to other countries. During the first half of the 19th century, the number of Dutch émigrés living in the Dutch East Indies was around 2100 persons. Following the opening of the Suez Canal in 1869, that number increased to around 11000 by the end of the 19th century. Emigration from the Netherlands to North America was not high during the 17th and 18th centuries - the number of people of Dutch descent in 1850 was only 10000 - but after 1840, the flow increased. During the period 18301914, approximately 250000 Dutch people emigrated to the United States. The first wave occurred between 1847 and 1857, with half of these persons belonging to a dissenting Protestant denomination. The second wave occurred later in the 19th century. The successive crop failures of potatoes and grain between 1847 and 1857, and the subsequent agrarian restructuring between 1880 and 1893, were influential push factors. Dutch migration to settlements in Brazil (1630-1654), Surinam (after 1667), and the Dutch Antilles was not extensive, and took place mostly in the 17th century, with a total of 15000 emigrating up to 1900. Dutch emigration to settlements elsewhere was also very limited. Until 1920, about 11000 Netherlanders settled in Canada, 4500 settled in Argentina, 3500 in Brazil, and 4000 in Australia. In 1914, 5000 Netherlanders lived in South Africa, a number that had been only 870 in 1891. After the Franco-Prussian War, when the German economy underwent a period of rapid expansion, many Dutch people went to Germany. The number of persons of Dutch descent living in Germany around 1860 was about 13000 , but by the outbreak of World War I, this had risen to more than 100000 . The number of persons of Dutch descent who had settled in Belgium in the mid-19th century was more than 30000 and, after 1900, about 60000 .

\section{Regional and religious differences}

Despite the relatively small size of the country, remarkable differences have always existed within the Netherlands, both by region and by religious group. The Netherlands has been divided geographically by the major rivers whose deltas they occupy - the Maas and the Rhine (Figure 2). Historically, these rivers created barriers to 


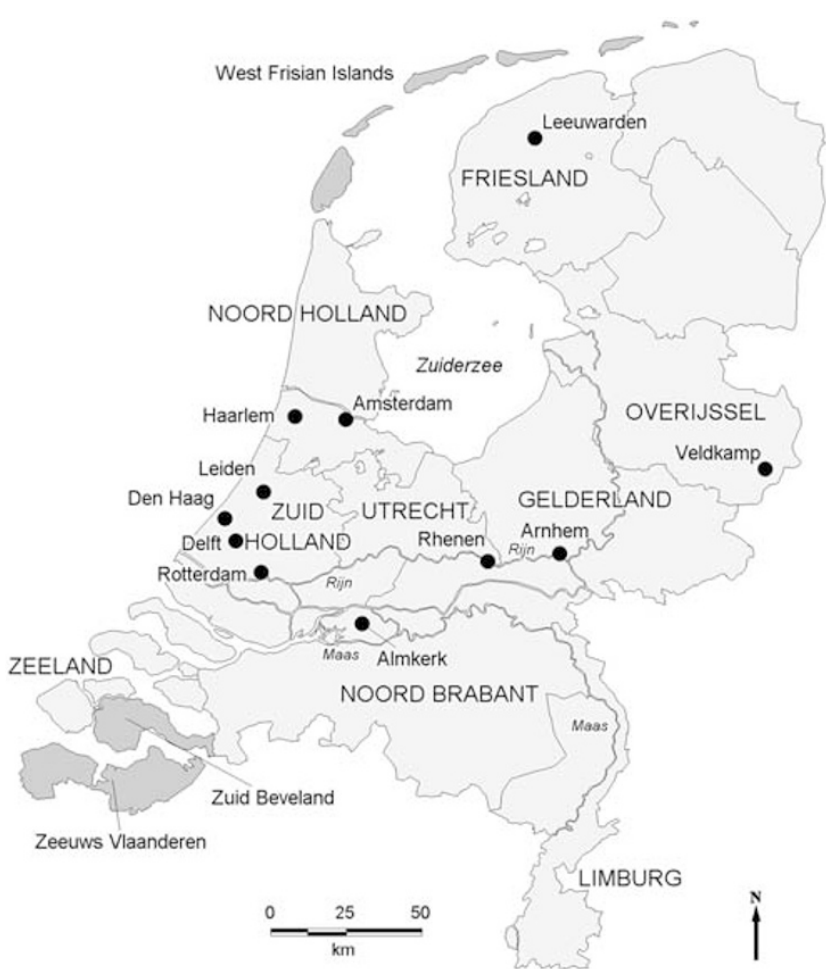

Figure 2 Map of the Netherlands with mentioned provinces (uppercase only), cities and regions (upper and lowercase), and rivers (Maas and Rijn or Rhine).

Note: To be in line with the historical description of the population and the geographical barriers described in the text, the map depicts the situation as it existed in 1920 . The reclamation of the inland sea (the Zuiderzee) between 1930 and 1968 has since then completely reshaped the topography. The part of the Zuiderzee that has survived as a lake is now called IJsselmeer. The southwest, which consisted of a series of islands and peninsulas has since the end of the 1950s with the Delta project also undergone profound changes in its topography, with stronger geographic links within the area and with the rest of the country as a result.

migration. Even greater geographic barriers were created for the people who lived on the West Frisian islands and for people who lived north of the Zuiderzee in Friesland (Figure 2, which describes the topographic situation around 1930 prior to the reclamation of the Zuiderzee).

Data on the spatial interaction of people from various regions have been studied using marriage certificates. In all provinces, the proportion of interprovincial marriages increased between 1902 and 1966, but the differences between the provinces in the South, the urbanized West, and Friesland (Figure 2) with low proportions and the rest with high rates of intermarriage did not disappear. ${ }^{24}$ Data for cities in East and West for the 19th century showed that geographic homogamy was lower in the West, partly as a consequence of the presence of a highly developed transport system and partly as the result of several population concentrations. ${ }^{25}$ Data for more isolated rural areas in the provinces of Zeeland and Noord-Brabant (Figure 2) showed much higher rates of endogamy. ${ }^{26}$

Marital endogamy was determined not only by spatial isolation but also by religious differences. Sharp religious cleavages and vehement debates on religious problems have been characteristic of the Netherlands since the Reformation. In that crucial period, only a part of the population joined the Protestant faith. Both in the early 1830s, and in the 1880s, a number of ministers broke away from the Netherlands Reformed Church and returned to the stricter orthodoxy of an earlier period; these secessions led to the development of the 'Gereformeerde Kerken', the Calvinists. The percentage of Roman Catholics remained fairly constant $(36.5 \%$ in $1869,36.4 \%$ in 1930$)$ and then increased slightly to $40.4 \%$ in 1971 . The proportion of Dutch Reformed (the name that is given to the members of the original State church) declined continuously particularly after 1880 , from 54.7 to $23.5 \%$ in $1971 .{ }^{27}$ The percentage of Calvinists (3\% in 1869) rose to $9.4 \%$ in 1971.

In its overall effect upon social and cultural participation, religion in the Netherlands was until recently of the utmost importance. From an early age onward, the population was divided into three separate blocs, who spent a great deal of their time in different environments. Religion determined the education that one received, the friends one had, and the choice of a spouse, the political party, and the trade union. Catholics and Calvinists, which constituted rather homogeneous and close-knit religious groupings with a marked identity of their own. The old distinctions between the southern provinces Limburg and North Brabant (85-95\% Catholic), and the northern parts, with less than 10\% Catholics, remained throughout the whole 19th and early 20th century. Outside the southern provinces, small concentrations of Roman Catholic groups could be found in a completely Protestant environment. This applied to parts of Friesland, Zeeuws-Vlaanderen in the province of Zeeland, Overijssel, Gelderland, and in the provinces of Holland (Figure 2).

A detailed long-term study of religious assortative mating in the West of the Netherlands showed that religious barriers during the first decades of the 19th century were considerable by modern standards and became even more insurmountable after $1890 .{ }^{28}$ Provincial data for the period 1938-41 show that $89 \%$ of Roman Catholics married within their own religion. The Dutch Reformed and Calvinists had high endogamy rates in the Western provinces and Limburg, where both groups of Protestants were a small minority. ${ }^{29}$ National data for the period $1938-$ 1983 showed a sharp increase in intermarriage for the Catholics and Calvinists, and a gradual increase among the 
Dutch Reformed. ${ }^{30}$ Religious endogamy in small communities was particularly high.

\section{Founder mutations}

To identify founder mutations among the Dutch and to put these into the context of Dutch demography, we searched the databases Pubmed and OMIM, through May 2003, using the terms, 'founder, mutation, Dutch, Netherlands, Holland, Surinam, Indonesia, East Indies, Afrikaner, and South Africa', with no language restriction. Furthermore, references cited in the published papers were examined until no further study was identified. A Dutch founder mutation was recognized when a disease mutation could be traced back to a common founder in the Netherlands or when the mutation was reported only among Dutch people. For clarity, we have assigned mutations into several categories: (1) genetic isolates, including large families, (2) Dutch-specific, when the mutation was only identified in the Netherlands, (3) European-shared, when the mutation was identified in the Netherlands and in at least one other population within the current European region, and (4) Dutch émigré, when the mutation was identified in Dutch émigré populations.

Where known, we present information about their mutant allele frequencies in affected and unaffected populations, the timing of their occurrence and their contemporary geographic distribution. When possible, we have calculated coalescence times of the founder mutations. The calculation of coalescence times is based on the average reproductive age of 30 years for men and women based on different observations. For women, the average was around 33-34 years in the period 1850-1870. This high age was partly due to high average numbers of children (between 4.5 and 5.0 per woman) partly to high ages at first marriage. The age at reproduction decreased to around age 31 after 1870, to decrease further after 1950 to a value of around 27 years in the middle of the 1970s. ${ }^{25}$ For men, data are available from 1812 onwards. ${ }^{31}$ Data show that, from 1865 onward, a decrease occurred in the age of fathers at the birth of their children from almost 36 to 34 years. This decrease lasted until 1900. After World War II, the same development was observed as among women. These data provide only national averages. Owing to strong differences in age at marriage and the number of children, ages at reproduction varied considerably over provinces and religious groups. For the period before 1800, no such information is available, but estimates might be given based on growth rates for various period. Subsequently, we have related coalescence times to events in Dutch history.

\section{Genetic isolates, including large families}

Several founder mutations have been identified among people who represent a religious, linguistic or geographic isolate within the Netherlands (Table 1). Among these are the mutations that cause benign familial cholestasis, ${ }^{32}$ type I diabetes mellitus, ${ }^{34}$ infantile neuronal ceroid lipofuscinosis, $^{35}$ triphalangeal thumb, ${ }^{37}$ and hereditary paragangliomas, ${ }^{38,39}$ These mutations have been found in large families or in individuals. Sometimes, the genealogy of these families is unknown, but has been demonstrated by probing village and church records, such as the study of individuals affected with type I diabetes mellitus. ${ }^{34}$ In the diabetes study, a review of these records demonstrated a common ancestor 15 generations prior to the proband generation, indicating that the founder mutation may have arisen during the late 16th century, when the Protestant Reformation contributed to population stratification.

Often, these families have been sentinel not only for mapping and cloning a gene, but also for demonstrating novel genetic phenomena. The studies of Dutch families with hereditary paragangliomas were the first to demonstrate a paternal imprinting effect for this disorder. ${ }^{37}$ This occurred at a time when the case for genetic imprinting in humans was being established. The study of three unrelated individuals from a geographically isolated fishing village in the Netherlands was one of the first to demonstrate the power of LD-mapping, a technique that has since generated widespread interest. ${ }^{33}$

Table 1 List of founder mutations from Dutch Genetic isolates, including large families

\begin{tabular}{|c|c|c|c|c|c|}
\hline Disease (reference) & Gene & Mutation & $\begin{array}{c}\text { Prevalence of } \\
\text { mutation among } \\
\text { affected }\end{array}$ & Regional distribution & $\begin{array}{l}\text { Coalescence } \\
\text { time }\end{array}$ \\
\hline Benign familial cholestasis 32,33 & ATP8B1 & & & $\begin{array}{l}\text { Three individuals in isolated } \\
\text { fishing village }\end{array}$ & \\
\hline Diabetes mellitus, type $\mathrm{I}^{34}$ & chr8q24 & & & $\begin{array}{l}\text { Isolated village in SW } \\
\text { Netherlands }\end{array}$ & 15 generations \\
\hline $\begin{array}{l}\text { Infantile neuronal ceroid } \\
\text { lipofuscinosis }\end{array}$ & CLN1 & T29A, C451T & & $\begin{array}{l}\text { Zeeland (large inbred } \\
\text { Catholic family) }\end{array}$ & \\
\hline Triphalangeal thumb ${ }^{37}$ & & & & $\begin{array}{l}\text { Two kindreds in an isolated } \\
\text { population }\end{array}$ & \\
\hline
\end{tabular}


Table 2 List of Dutch specific founder mutations

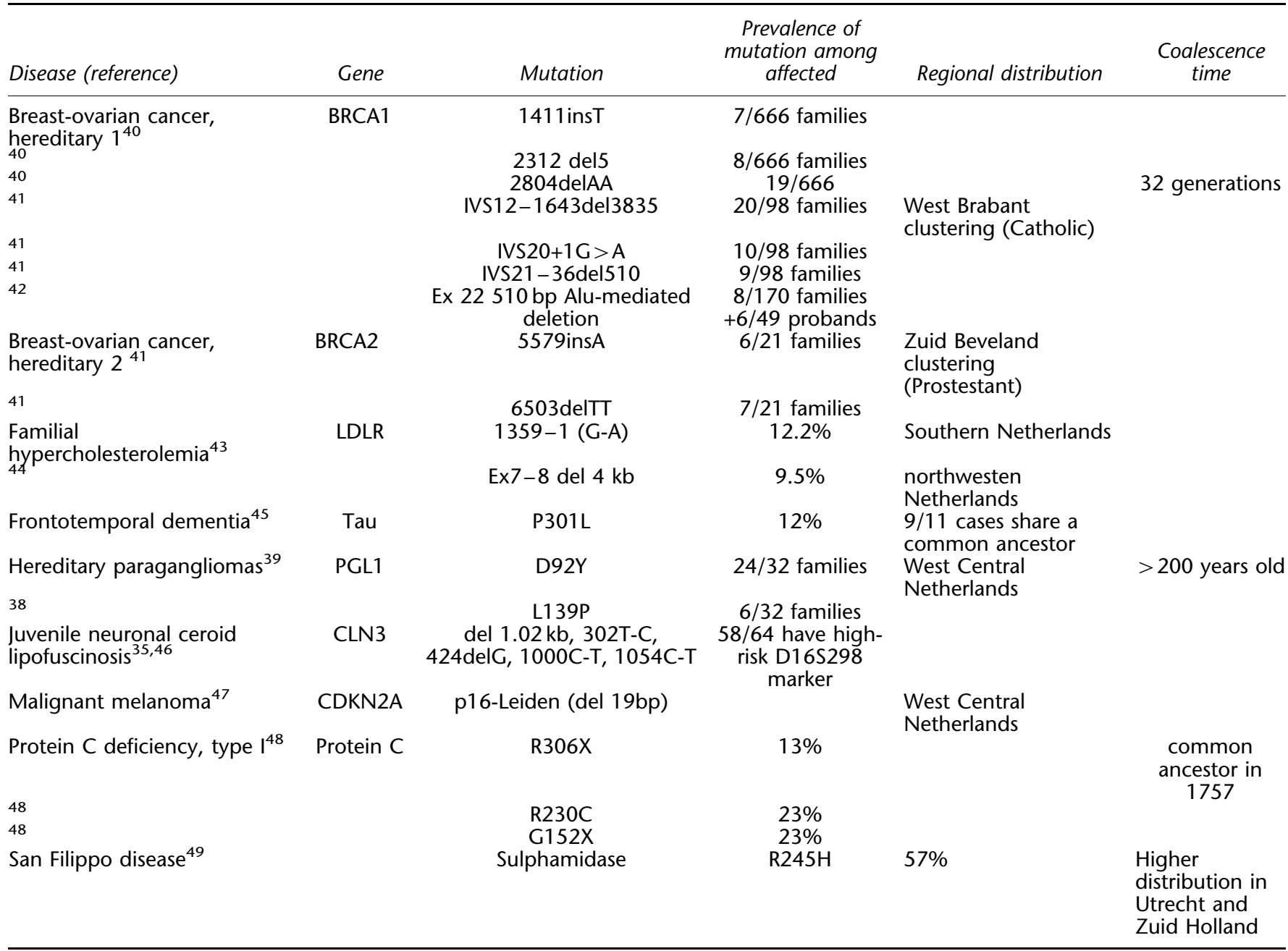

\section{Dutch-specific}

Many mutations have been described specifically in the Netherlands (Table 2). The frequency of these mutations is variable. Some mutations are predominant causes of the disease among Dutch probands. For example, 57\% of the alleles of patients with San Filippo A disease are identified with the sulphamidase R245H mutation, ${ }^{49}$ and the BRCA2 5579insA and 6503delTT mutations account for $62 \%$ of hereditary breast and ovarian cancer linked to this gene. ${ }^{41}$ For hereditary breast and ovarian cancer, many Dutchspecific mutations in the BRCA1 gene are causative, with none being predominant. ${ }^{41,40}$ For familial hypercholesterolemia and for frontotemporal dementia, the Dutchspecific mutations are responsible for a relatively low proportion of cases. ${ }^{43,45,50}$

The time of origin for most of these Dutch-specific founder mutations is unknown; however, there are a few exceptions and these span contemporary Dutch history. A common ancestor was identified for probands with the Protein C deficiency mutation R306X, ${ }^{48}$ and for probands with the Tau frontotemporal dementia mutation P301L. ${ }^{45}$ The common ancestor with the Protein C deficiency mutation lived in 1757. The founder mutation for the BRCA1 2804delAA mutation was calculated to have arisen during the same era (200 years ago). Based on coalescence time calculation, the founder mutations for the PGL1 D92Y mutation may have occurred 960 years ago (32 generations) ${ }^{39,40}$ when regional Dutch sovereignty was being established following the collapse of the Carolingian empire.

For many mutations, common origins have not been demonstrated on the basis of shared haplotypes, so that recurrent mutation cannot be excluded. Yet, for some of these conditions, mutations show regional distribution, suggesting the general location in which the mutation may have arisen and then fanned out. For example, the sulphamidase $\mathrm{R} 245 \mathrm{H}$ mutation that causes San Filippo 
disease has a higher distribution in Utrecht and Zuid Holland (Figure 2). ${ }^{49}$ Two LDL receptor mutations that cause familial hypercholesterolemia have different regional distributions. The 1359-1 G-A mutation is found predominantly in the southern Netherlands and the exon 7-8 $4 \mathrm{~kb}$ deletion is found predominantly in the northwestern Netherlands. ${ }^{43,44}$ The BRCA1 IVS12-1643del3835 is found predominantly among Catholic families in the western part of Noord Brabant and the BRCA2 5579insA mutation is found predominantly among Protestant families in Zuid Beveland (Figure 2). ${ }^{41}$

\section{Allele sharing with other European populations}

The Dutch share founder mutations with other European populations for many conditions, including acute intermittent porphyria, ${ }^{51}$ congenital disorders of glycosylation, type $1 \mathrm{a},{ }^{52}$ cystic fibrosis, ${ }^{53}$ familial hypercholesterolemia, ${ }^{43}$ generalized atrophic benign epidermolysis bullosa, ${ }^{54}$ glycogen storage disease II, ${ }^{55-57}$ Krabbe disease, ${ }^{58}$ medium chain acyl-coA dehydrogenase deficiency, ${ }^{59}$ Stargardt disease, ${ }^{60}$ and cone-rod dystrophy. ${ }^{60}$ (see Table 3) The frequency of these mutations as a cause of these diseases is variable, ranging from 4 to $94 \%$. A single mutation is the major cause of the disease within the Netherlands, for generalized atrophic benign epidermolysis bullosa (COL17A1 2342delG), ${ }^{54}$ cystic fibrosis (CFTR deltaF508), ${ }^{49}$ Krabbe disease (GALC IVS10del30 kb), ${ }^{58}$ and MCAD deficiency (MCAD K304E). ${ }^{59}$ The Dutch/non-Dutch distinction may be arbitrary for many conditions, and may reflect that comparable studies for some of these mutations have not been performed in other European populations. Some of these mutations, including MCAD K304E, ${ }^{59}$ and CFTR deltaF508, ${ }^{53}$ show northwest to southeast clines across Europe.

\section{Dutch émigré populations}

Founder mutations of Dutch origin have been found among the descendants of Dutch émigrés. Emigration was often by people who shared the same region of origin and the same religion, which could have had an effect on the genetic pool observed in the regions of destination. Unfortunately, no literature about founder mutations in the East Indies was identified. This may be caused by the fact that relatively little research on this topic has been performed in this country and that the Dutch were a nonstable, temporary group of migrants, who did not intend to settle there forever. During the independence of Indonesia, most Dutch descendents immigrated back to the Netherlands, limiting the possibility for Dutch genes to permeate the East Indies.

The LDL receptor mutations of Dutch origin have been observed among Canadians with Dutch ancestry and among Afrikaners in South Africa (Table 4). ${ }^{43}$ Much like

Table 3 List of founder mutations shared with other European populations

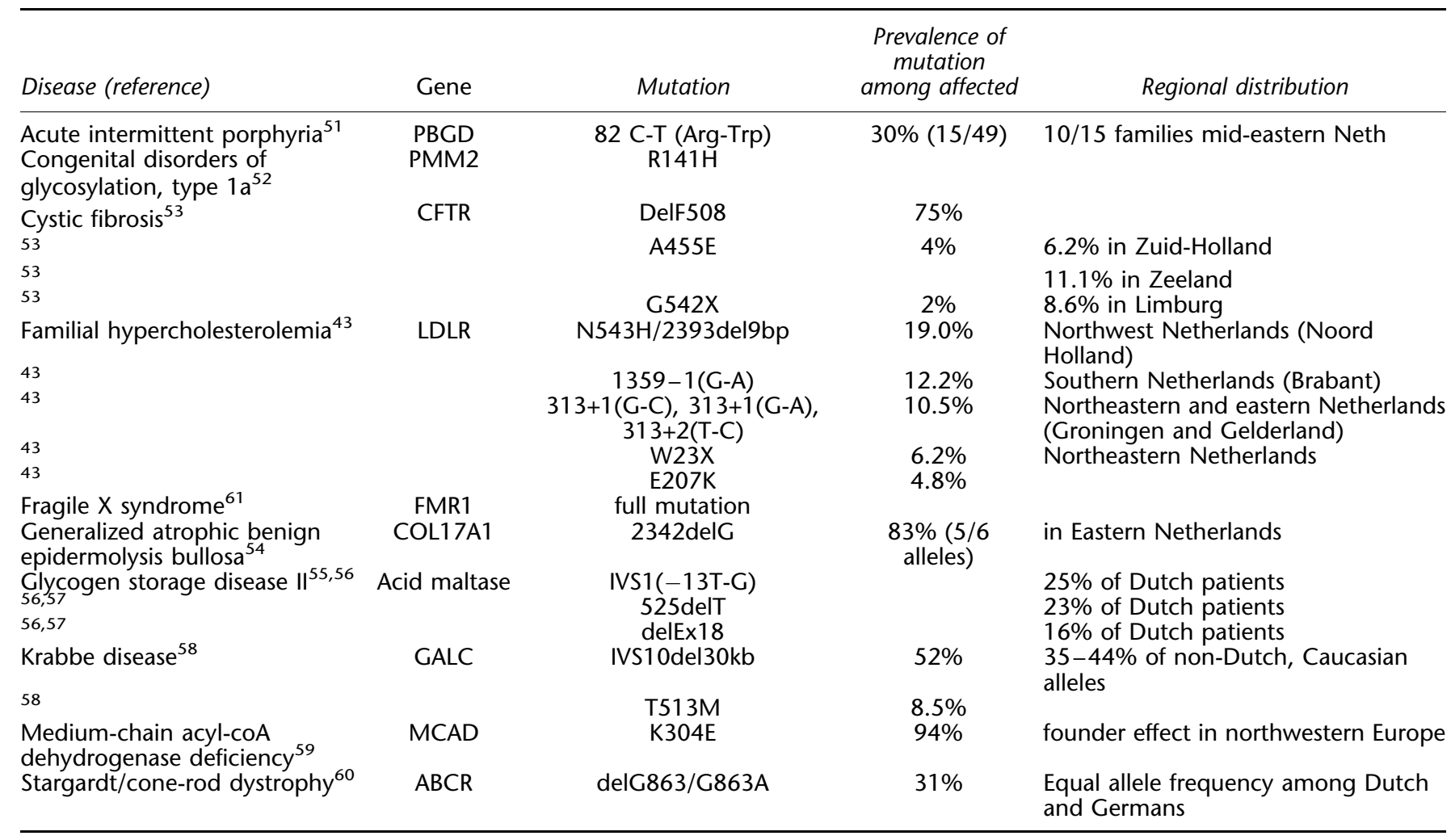


Table 4 List of founder mutations among Afrikaners

\begin{tabular}{|c|c|c|c|c|}
\hline Disease (reference) & Gene & Mutation & $\begin{array}{l}\text { Prevalence of } \\
\text { mutation among } \\
\text { affected }\end{array}$ & Other populations \\
\hline $\begin{array}{l}\text { Cystic fibrosis } \\
62\end{array}$ & CFTR & $\begin{array}{l}\text { DelF508 } \\
\text { 394delTT }\end{array}$ & $\begin{array}{l}76 \% \\
3.60 \%\end{array}$ & Finland, Belgium, Denmark \\
\hline $\begin{array}{l}62 \\
\text { Familial hypercholesterolemia }\end{array}$ & LDLR & $\begin{array}{l}3272-26 \mathrm{~A} \rightarrow \mathrm{G} \\
\mathrm{D} 206 \mathrm{E} \\
\mathrm{M} 408 \mathrm{~V}\end{array}$ & $\begin{array}{l}4.00 \% \\
69 \% \\
15 \%\end{array}$ & France, Canada, Portugual \\
\hline $\begin{array}{l}\text { Fanconi anemia }{ }^{63} \\
63 \\
63\end{array}$ & FANCA & $\begin{array}{l}\text { DelE12-31 } \\
\text { DelE11-17 } \\
\text { 3398delA }\end{array}$ & $\begin{array}{c}15 \% \\
60 \% \\
13 \% \\
7 \%\end{array}$ & $\begin{array}{l}3.1 \% \text { of Dutch } \mathrm{FH} \text { patients } \\
1 \text { German from Western Rurh }\end{array}$ \\
\hline $\begin{array}{l}\text { Hypertrophic cardiomyopathy } \\
64,65\end{array}$ & betaMHC & $\begin{array}{l}\text { R403Y } \\
\text { A797T }\end{array}$ & $25 \%$ & \\
\hline $\begin{array}{l}\text { V4 } \\
\text { Variegate porphyria }\end{array}$ & $\begin{array}{l}\text { CTnT } \\
\text { PPOX }\end{array}$ & $\begin{array}{l}\text { R92Y } \\
\text { R59W } \\
\text { R168C }\end{array}$ & & \\
\hline 66,67 & & $\mathrm{H} 20 \mathrm{P}$ & & \\
\hline
\end{tabular}

the Dutch themselves, Afrikaners are an endogamous population with Dutch, French Huguenot, and German ancestry. The multiple European origins have been observed for the Afrikaaner founder mutations for variegate porphyria PPOX R59W, ${ }^{66,67}$ CFTR delF508, 394delTT, and $3272-26 \mathrm{~A} \rightarrow \mathrm{G}^{62}$ the ${ }^{6 D R}$ receptor $\mathrm{M} 408 \mathrm{~V},{ }^{43}$ and the Fanconi anemia A deletion exons $12-31 .{ }^{63}$

Founders have been identified for mutations that cause Leber hereditary optic neuropathy (LHON) and acute intermittent porphyria in Dutch émigré populations. LHON is caused by mutation in the mitochondrial DNA (mtDNA). Recently, analysis of the 55 large Dutch pedigrees showed several instances in which the mtDNA mutations were either identical or related by descent. ${ }^{68}$ The most striking was a Dutch founder mtDNA 14484 mutation on a haplogroup $\mathrm{J}$ background that had an identical sequence in two Canadian LHON pedigrees, indicating a common ancestor. This mutation must have occurred prior to the European settlement of Canada in the 1600s. A total of 10 families with the 14484 mutation of the haplogroup J were traced to a female ancestor who was born in 1613 in the town of Rhenen (Figure 2). Another pedigree could be traced back to woman who was born in Rhenen in 1745 and another to a woman born around 1678 in Almkerk (Figure 2). In addition, there were two 14484/haplotype $K$ pedigrees that could be traced to a woman born in Leeuwarden (Figure 2) circa 1760. ${ }^{68}$

The South African variegate porphyria PPOX R59W could be traced back to Gerrit Jansz van Deventer, born in Veldkamp (Figure 2) in the Netherlands, and to his wife Ariaentje Jacobs, who was born in Rotterdam (Figure 2). Her father died when she was 5 months and her mother, when she was eight. Admitted to the orphanage 'Gereformeerd Burgersweeshuis' in Rotterdam, in 1687, the director minister Sewentien decided to send eight of his female orphans (including Ariaentje and her half-sister Willemijntje) to the Cape to become wives of the Dutch settlers. She married Gerrit Jansz van Deventer, and he and his wife had eight children, of whom four had porphyria. The link with this founder family was identified first by Geoffrey Dean, a British physician who settled in South Africa in $1947 .{ }^{69}$ He could determine whether Ariaentje or her husband, Gerrit Jansz, carried the mutation. Based on the fact that Hendrik, the son of the halfsister, Willemijntje, also had porphyria the mutation, the carrier was assumed to be Ariaentje.

A cluster of porphyria was also identified in a community southeast of Portland, Oregon (Robert Vlietinck, unpublished results). These people were descended from seven founders who all emigrated to the United States in the middle of the 19th century. They were endogamous to keep the farming land in the families. Their ancestry could be traced back to the province of North-Brabant, not far away from the village Veldkamp, where Gerrit Jansz van Deventer was born.

\section{Implications for clinical genetic testing and gene discovery}

The presence of so many founder mutations among the Dutch could lead to efficient testing based on genotype for diagnosis or presymptomatic diagnosis for the conditions listed in these tables. Even for autosomal recessive disorders, the presence of even one founder mutation in a symptomatic patient would increase the likelihood of the disease and would suggest looking for a second mutation by DNA sequencing or other scanning method. Likewise, heterozygote screening for autosomal recessive conditions for reproductive genetic counseling could be efficient and tailored to specific regions of the Netherlands, where certain allele frequencies are known to be higher. For many conditions, however, the carrier frequencies and 
regional distributions are unknown; thus, additional research is required before such programs could be implemented.

The occurrence of short chromosomal regions that have remained identical by descent has resulted in relatively limited genetic heterogeneity for many genetic conditions among the Dutch, leading to recognizable associations of founder mutations with linked marker alleles. This could make gene discovery more efficient for conditions that have a genetic basis, thus far unidentified. The presence of large Dutch families and some genetic isolates within the Dutch population create unique opportunities for gene discovery, as has been demonstrated already.

\section{Suggested next steps}

Prior to realizing the potential for genetic testing and gene discovery in the Dutch population, several next steps are recommended. Population genetic studies for known mutations to determine allele frequencies and their regional distributions could lead to more precise recommendations for genetic testing. The development of a Dutch DNA testing chip could make such a study very efficient. ${ }^{13}$ The development of a Dutch haplotype map could increase the efficiency of gene discovery and genetic epidemiology studies. LD studies to understand the timing of mutations and forces that may have influenced the distribution would lead to a more complete understanding of contemporary Dutch population genetics.

\section{Acknowledgements}

The authors thank Peter Ekamper for designing the map in Figure 2.

\section{References}

1 de la Chapelle A, Wright FA: Linkage disequilibrium mapping in isolated populations: the example of Finland revisited. Proc Natl Acad Sci USA 1998; 95: 12416-12423.

2 Pauling L, Itano HA, Singer SJ, Wells IC: Sickle cell anemia: a molecular disease. Science 1949; 110: 543.

3 Slaugenhaupt SA, Blumenfeld A, Gill SP et al: Tissue-specific expression of a splicing mutation in the IKBKAP gene causes familial dysautonomia. Am J Hum Genet 2001; 68: 598-605.

4 Zlotogora J: High frequencies of human genetic diseases: founder effect with genetic drift or selection? Am J Med Genet 1994; 49: $10-13$.

5 Kronn D, Oddoux C, Phillips JH: Prevalence of Canavan disease heterozygotes in the New York metropolitan Ashkenazi Jewish population. Am J Hum Genet 1995; 57: 1250-1252.

6 Pastinen T, Perola M, Ignatius J et al: Dissecting a population genome for targeted screening of disease mutations. Hum $\mathrm{Mol}$ Genet 2001; 10: 2961-2972.

7 Struewing JP, Hartge P, Wacholder S et al: The risk of cancer associated with specific mutations of BRCA1 BRCA2 among Ashkenazi Jews. New Engl J Med 1997; 336: 1401-1408.

8 Oddoux C, Struewing JP, Clayton CM et al: The carrier frequency of the BRCA2 6174delT mutation among Ashkenazi Jewish individuals is approximately 1\%. Nat Genet 1996; 14: 188-190.

9 Reich DE, Cargill M, Bolk S et al: Linkage disequilibrium in the human genome. Nature 2001; 411: 199-204.

10 Hastbacka J, de la Chapelle A, Kaitila I, Sistonen P, Weaver A, Lander E: Linkage disequilibrium mapping in isolated founder populations: diastrophic dysplasia in Finland (published erratum appears in Nat. Genet. 2(4):343, 1992). Nat Genet 1992; 2: 204-211.

11 Risch N, Merikangas K: The future of genetic studies of complex human diseases. Science 1996; 273: 1516-1517.

12 Ostrer H: A genetic profile of contemporary Jewish populations. Nat Rev Genet 2001; 2: 891-898.

13 Peltonen L, Jalanko AT: Molecular genetics of the Finnish disease heritage. Hum Mol Genet 1999; 8: 1913-1923.

14 Zschocke J: Phenylketonuria mutations in Europe. Hum Mutat 2003; 21: 345-356.

15 Cunliffe B: The Oxford Illustrated Prehistory of Europe, New York: Oxford University Press; 1994.

16 Torroni A, Bandelt HJ, Macaulay V et al: A signal from human mtDNA of postglacial recolonization in Europe. Am J Hum Genet 2001; 69: 844-852.

17 Semino O, Passarino G, Oefner PJ et al: The genetic legacy of paleolithic Homo sapiens in extant Europeans: a Y chromosome perspective. Science 2000; 290: 1155-1159.

18 Rosser ZH, Zerjal T, Hurles ME et al: Y-chromosomal diversity in Europe is clinal influenced primarily by geography rather than by language. Am J Hum Genet 2000; 67: 1526-1543.

19 Renfrew C: Archeology Language: The Puzzle of Indo-European Origins. London: Jonathan Cape; 1987.

20 Rietbergen PJAN, Seegers GHJ: A Short History of the Netherlands: From Prehistory to Present Day. Amersfoort: Bekking Publishers; 1992.

21 Van der Woude AM: Demografische ontwikkeling van de noordelijke nederlanden 1500-1800. in Algemene geschiedenis der Nederlanden. Haarlem: Fibula; 1980.

22 Lucassen J: 'Dutch migration 1600-1900'. in Eiras A (ed): Long Distance Migrations (1500-1900). Madrid: Commission Internationale de Démographie Historique; 1990.

23 Stokvis PRD: Dutch international migration 1815-1910. in Swierenga RP(ed) The Dutch in America. Immigration, Settlement and Cultural Change. New Brunswick: Rutgers University Press; 1985.

24 Knippenberg $\mathrm{H}$, dePater B: De eenwording van Nederland. Nijmegen: SUN; 1988

25 van Poppel F: Verbreding van de horizon? veranderingen in geografische herkomst van huwelijkspartners. Acta Geograph Lovaniensia 1994; 34: 79-88.

26 Kok J: 'Vrijt daar je zijt'; Huwelijk en partnerkeuze in Zeeland tussen 1830 en 1950 . Zeeland; 1998; 7: 131-143.

27 Knippenberg H: De religieuze kaart van Nederland: omvang en geografisch spreiding van de godsdienstige gezindten vanaf de reformatie tot heden. Assen: Van Gorcum; 1992.

28 Beekink E, Liefbroer A, Poppel F: Changes in choice of spouse as an indicator of a society in a state of transition: Woerden 18301930. Historical Social Res 1998; 23: 231-253.

29 Polman A: Geografische en confessionele invloeden bij de huwelijkskeuze in Nederland. Leiden: Stenfert kroese; 1951.

30 Hendrickx J: The Analysis of Religious Assortative Marriage. An Application of Design Techniques for Categorical Models. Amsterdam: Thesis Publishers; 1994.

31 Van Poppel F, Mandemakers K, Vaders op leeftijd : Vergelijking met de 19e eeuw. Demos 2002; 18: 13-16.

32 Bull LN, van Eijk MJ, Pawlikowska L et al: A gene encoding a Ptype ATPase mutated in two forms of hereditary cholestasis. Nat Genet 1998; 18: 219-224.

33 Houwen RH, Baharloo S, Blankenship $\mathrm{K}$ et al: Genome screening by searching for shared segments: mapping a gene for benign recurrent intrahepatic cholestasis. Nat Genet 1994; 8: $380-386$.

34 Vaessen N, Heutink P, Houwing-Duistermaat JJ et al: A genomewide search for linkage-disequilibrium with type 1 diabetes in a recent genetically isolated population from the netherlands. Diabetes 2002; 51: 856-859.

35 Taschner PE, Franken PF, van Berkel L, Breuning MH: Genetic heterogeneity of neuronal ceroid lipofuscinosis in the Netherlands. Mol Genet Metab 1999; 66: 339-343. 
36 van den Heuvel LP, Luiten B, Smeitink JA et al: A common point mutation in the tyrosine hydroxylase gene in autosomal recessive L-DOPA-responsive dystonia in the dutch population. Hum Genet 1998; 102: 644-646.

37 Heutink P, Zguricas J, van Oosterhout L et al: The gene for triphalangeal thumb maps to the subtelomeric region of chromosome 7q. Nat Genet 1994; 6: 287-292.

38 Taschner PE, Jansen JC, Baysal BE et al: Nearly all hereditary paragangliomas in the Netherlands are caused by two founder mutations in the SDHD gene. Genes Chromosomes Cancer 2001; 31: $274-281$.

39 van Schothorst EM, Jansen JC, Grooters E et al: Founder effect at PGL1 in hereditary head neck paraganglioma families from the Netherlands. Am I Hum Genet 1998; 63: 468-473.

40 Peelen T, van Vliet M, Petrij-Bosch A et al: A high proportion of novel mutations in BRCA1 with strong founder effects among Dutch Belgian hereditary breast ovarian cancer families. Am J Hum Genet 1997; 60: 1041-1049.

41 Verhoog LC, van den Ouweland AM, Berns E et al: Large regional differences in the frequency of distinct BRCA1/BRCA2 mutations in 517 Dutch breast and/or ovarian cancer families. Eur J Cancer 2001; 37: 2082-2090.

42 Petrij-Bosch A, Peelen T, van Vliet $\mathrm{M}$ et al: BRCA1 genomic deletions are major founder mutations in Dutch breast cancer patients. Nat Genet 1997; 17: 341-345.

43 Fouchier SW, Defesche JC, Umans-Eckenhausen MW, Kastelein JP: The molecular basis of familial hypercholesterolemia in the Netherlands. Hum Genet 2001; 109: 602-615.

44 Top B, Koeleman BP, Gevers Leuven JA, Havekes LM, Frants RR: Rearrangements in the LDL receptor gene in Dutch familial hypercholesterolemic patients the presence of a common $4 \mathrm{~kb}$ deletion. Atherosclerosis 1990; 83: 127-136.

45 Rizzu P, Van Swieten JC, Joosse M et al: High prevalence of mutations in the microtubule-associated protein tau in a population study of frontotemporal dementia in the Netherlands. Am J Hum Genet 1999; 64: 414-421.

46 Taschner JG, de Vos N, Post JG et al: Carrier detection of Batten disease (juvenile neuronal ceroid-lipofuscinosis). Am J Med Genet 1995; 57: 333-337.

47 Gruis NA, van der Velden PA, Sandkuijl LA et al: Homozygotes for CDKN2 (p16) germline mutation in Dutch familial melanoma kindreds. Nat Genet 1995; 10: 351-353.

48 Reitsma PH, Poort SR, Allaart CF, Briet E, Bertina RM: The spectrum of genetic defects in a panel of 40 Dutch families with symptomatic protein $\mathrm{C}$ deficiency type I: heterogeneity founder effects. Blood 1991; 78: 890-894.

49 Weber B, van de Kamp JJ, Kleijer WJ et al: Identification of a common mutation (R245H) in sanfilippo a patients from the netherlands. J Inherit Metab Dis 1998; 21: 416-422.

50 Poorthuis BJ, Wevers RA, Kleijer WJ et al: The frequency of lysosomal storage diseases in the Netherlands. Hum Genet 1999; 105: $151-156$.

$51 \mathrm{Gu}$ XF, de Rooij F, Lee JS et al: High prevalence of a point mutation in the porphobilinogen deaminase gene in Dutch patients with acute intermittent porphyria. Hum Genet 1993; 91: $128-130$

52 Schollen E, Kjaergaard S, Legius E, Schwartz M, Matthijs G: Lack of Hardy-Weinberg equilibrium for the most prevalent PMM2 mutation in CDG-Ia (congenital disorders of glycosylation type Ia). Eur J Hum Genet 2000; 8: 367-371.
53 Collee JM, de Vries HG, Scheffer H, Halley DJ, ten Kate LP: Relative frequencies of cystic fibrosis mutations in The Netherlands as an illustration of significant regional variation in a small country. Hum Genet 1998; 102: 587-590.

54 Scheffer H, Stulp RP, Verlind E et al: Implications of intragenic marker homozygosity haplotype sharing in a rare autosomal recessive disorder: the example of the collagen type XVII (COL17A1) locus in generalised atrophic benign epidermolysis bullosa. Hum Genet 1997; 100: 230-235.

55 Kroos MA, Van der Kraan M, Van Diggelen OP et al: Glycogen storage disease type II: frequency of three common mutant alleles their associated clinical phenotypes studied in 121 patients. J Med Genet 1995; 32: 836-837.

56 Ausems MG, Verbiest J, Hermans MP et al: Frequency of glycogen storage disease type II in The Netherlands: implications for diagnosis genetic counseling. Eur J Hum Genet 1999; 7: 713-716.

57 Ausems MG, ten Berg K, Sandkuijl LA et al: Dutch patients with glycogen storage disease type II show common ancestry for the 525delT del exon 18 mutations. J Med Genet 2001; 38: 527-529.

58 Kleijer WJ, Keulemans JL, van der Kraan M et al: Prevalent mutations in the GALC gene of patients with Krabbe disease of Dutch and other European origin. J Inherit Metab Dis 1997; 20: 587-594.

59 Gregersen N, Winter V, Curtis D et al: Medium-chain acyl-CoA dehydrogenase (MCAD) deficiency: the prevalent mutation G985 (K304E) is subject to a strong founder effect from Northwestern Europe. Hum Hered 1993; 43: 342-350.

60 Maugeri A, van Driel MA, van de Pol DJ et al: The 2588G-\&gt;C mutation in the ABCR gene is a mild frequent founder mutation in the Western European population allows the classification of ABCR mutations in patients with Stargardt disease. Am J Hum Genet 1999; 64: 1024-1035.

61 Buyle S, Reyniers E, Vits L et al: Founder effect in a Belgian-Dutch fragile X population. Hum Genet 1993; 92: 269-272.

62 Goldman A, Labrum R, Claustres $\mathrm{M}$ et al: The molecular basis of cystic fibrosis in South Africa. Clin Genet 2001; 59: 37-41.

63 Tipping AJ, Pearson T, Morgan NV et al: Molecular genealogical evidence for a founder effect in Fanconi anemia families of the Afrikaner population of South Africa. Proc Natl Acad Sci USA 2001; 98: $5734-5739$.

64 Moolman-Smook JC, De Lange WJ, Bruwer EC, Brink PA, Corfield VA: The origins of hypertrophic cardiomyopathy-causing mutations in two South African subpopulations: a unique profile of both independent founder events. Am J Hum Genet 1999; 65: 1308-1320.

65 Moolman-Smook J, De Lange W, Corfield V, Brink P: Expression of HCM causing mutations: lessons learnt from genotypephenotype studies of the South African founder MYH7 A797T mutation. J Med Genet 2000; 37: 951-956.

66 Meissner PN, Dailey TA, Hift RJ et al: A R59W mutation in human protoporphyrinogen oxidase results in decreased enzyme activity is prevalent in South Africans with variegate porphyria. Nat Genet 1996; 13: 95-97.

67 Warnich L, Kotze MJ, Groenewald IM et al: Identification of three mutations associated haplotypes in the protoporphyrinogen oxidase gene in South African families with variegate porphyria. Hum Mol Genet 1996; 5: 981-984.

68 Howell N, Oostra R, Bolhuis P et al: Sequence analysis of the mitochondrial genomes from Dutch pedigrees with Leber hereditary optic neuropathy. Am J Hum Genet 2003; 72: 1460-1469.

69 Dean G: The Porphyrias: A story of inheritance and environment. Philadelphia: J.B. Lippincott; 1963. 